\title{
Sensitivity analysis of the multispecies virtual population analysis model parameterized for a system of trophically-linked species from the eastern Bering Sea
}

\section{Análisis de sensibilidad del modelo de análisis poblacional virtual multiespecífico aplicado a un sistema de especies relacionadas tróficamente del Mar de Bering Oriental}

\author{
Jesús Jurado-Molina ${ }^{1 *}$ \\ Patricia Livingston ${ }^{2}$ \\ Vincent F. Galluci ${ }^{1}$ \\ ${ }^{1}$ School of Aquatic and Fishery Sciences \\ University of Washington \\ Box 355020 \\ Seattle, WA 98195, USA \\ *E-mail: jjurado@u.washington.edu \\ ${ }^{2}$ National Marine Fisheries Service \\ Alaska Fisheries Science Center \\ 7600 Sand Point Way NE \\ Seattle, WA 98115, USA
}

Recibido en diciembre de 2002; aceptado en noviembre de 2003

\begin{abstract}
A sensitivity analysis of a multispecies virtual population analysis (MSVPA) model parameterized for the Bering Sea was carried out using two methods for the analysis. In the first method, four variables related to the predation mortality $M 2$ and population size of age-1 walleye pollock (Theragra chalcogramma) and Pacific cod (Gadus macrocephalus) were chosen as response variables. Results suggested that the response variables of walleye pollock were sensitive to the residual mortality $M 1$ of walleye pollock, the stock size of arrowtooth flounder (Atheresthes stomias) and ration of both predator species. Pacific cod response variables were sensitive only to variables related to Pacific cod. These results reinforce the importance of cannibalism in the dynamics of walleye pollock and Pacific cod. Results from the individual perturbation parameter analysis showed that the changes produced by large positive perturbations in the "other food" parameter were small. The overall results suggest that the MSVPA model can be considered robust. These results help to recognize the potential use of MSVPA as a tool to assist in broadening the management of the fishery resources from the Bering Sea within a multispecies perspective.
\end{abstract}

Key words: sensitivity analysis, MSVPA, predation mortality, walleye pollock, Bering Sea.

\section{Resumen}

Se llevó a cabo un análisis de sensibilidad para el modelo de análisis de población virtual multiespecifico (MSVPA, por sus siglas en inglés) aplicado al Mar de Bering con dos métodos distintos. Con el primer método, se consideraron variables de respuesta a cuatro variables relacionadas con la mortalidad por depredación $M 2$ y el tamaño de la población de un año de edad de abadejo de Alaska (Theragra chalcogramma) y bacalao del Pacífico (Gadus macrocephalus). Los resultados sugirieron que las variables de respuesta del abadejo de Alaska fueron sensibles a la mortalidad residual $M 1$ del propio abadejo, a la magnitud del stock de Atheresthes stomias y a la ración de ambas especies. Las variables de respuesta del bacalao del Pacífico fueron sensibles únicamente a variables relacionadas con la misma especie. Estos resultados refuerzan la importancia del canibalismo en la dinámica tanto del abadejo de Alaska como del bacalao del Pacífico. Los resultados del análisis de perturbación mostraron que los cambios causados por las perturbaciones positivas grandes en el parámetro "otras presas" ("other food" en inglés) fueron pequeños. Los resultados de ambos análisis de sensibilidad sugieren que el modelo MSVPA puede ser considerado robusto. Este resultado ayuda a reconocer el uso potencial del modelo MSVPA como una herramienta útil para incluir el manejo de los recursos pesqueros del Mar de Bering dentro de una perspectiva multiespecífica.

Palabras clave: análisis de sensibilidad, MSVPA, mortalidad por depredación, abadejo de Alaska, Mar de Bering. 


\section{Introduction}

Fisheries management has been based on single-species models; however, there is an increasing tendency to recognize that the dynamics of a fishery could be determined by external factors such as the environment and interactions with other species. Thus, a broader approach to management that provides information about the potential consequences of fishing on the ecosystem is necessary. In particular, multispecies models are useful to measure the indirect effects related to changes in the flow of energy through the ecosystem (Hollowed et al., 2000). Several multispecies models have been developed in the last two decades with different emphasis, including biological, technological or economical interactions. Numerous models have incorporated trophic interactions. In particular, in the North Pacific, Livingston and Methot (1998) incorporated the effect of predation by three species into an age-structured model for walleye pollock (Theragra chalcogramma) in the Bering Sea. This methodology made possible the estimation of predation mortality of walleye pollock and suggested that cannibalism may be an important factor in determining recruitment into fishery. Hollowed et al. (2000) included the effect of predation by the arrowtooth flounder (Atheresthes stomias), Pacific halibut (Hippoglossus stenolepis) and Steller sea lion (Eumetopias jubatus) in a separable catch-at-age stock assessment model for walleye pollock in the Gulf of Alaska. Predation by these predators was defined as an additional type of fishery. The approach taken in these two models did not consider the feedback between predators and prey, which may be important. Two models that consider this type of feedback have also been developed for the eastern Bering Sea (Livingston and Jurado-Molina, 2000; Aydin et al., 2002).

A multispecies virtual population analysis (MSVPA) model and a multispecies forecast (MSFOR) model were developed for the eastern Bering Sea (Livingston and Jurado-Molina, 2000; Jurado-Molina and Livingston, 2002a). These models were developed by the Multispecies Working Group of the International Council for the Exploration of the Seas (ICES) based on the assumption of multispecies interactions and predator-prey preferences proposed by Anderson and Ursin (1977). MSVPA is an extension of the virtual population analysis (VPA) model (Gulland, 1965) that estimates population parameters and predation mortality based on catch-at-age, predator ration and predator diet information. A more detailed description of the equations and the assumptions from MSVPA can be found in Sparre (1991) and Magnusson (1995).

The MSFOR is the predictive counterpart of the MSVPA and uses the exponential equation to forecast the population dynamics:

$$
N_{a+1, t+1}=N_{a, t} e^{-(F+M 1+M 2)}
$$

where $F$ represents the fishing mortality, $M 1$ the residual mortality (due to ageing, starvation, etc.) and $M 2$ the predation

\section{Introducción}

La administración pesquera se ha basado en modelos monoespecíficos; sin embargo, hay una tendencia a reconocer que la dinámica de una pesquería podría estar determinada por factores externos tales como el medio ambiente e interacciones con otras especies. Debido a esto se requiere un enfoque más amplio que provea información acerca de las probables consecuencias de la pesca sobre el ecosistema. En particular, los modelos multiespecíficos son útiles para medir los efectos indirectos relacionados con cambios en el flujo de energía a través del ecosistema (Hollowed et al., 2000). En las últimas dos décadas se han desarrollado varios modelos multiespecíficos con énfasis en diferentes aspectos, tales como las interacciones biológicas, tecnológicas y económicas. Algunos modelos han incorporado interacciones tróficas. En particular en el Pacífico norte, Livingston y Methot (1998) incorporaron el efecto de la depredación por tres especies en un modelo con estructura de edad para el abadejo de Alaska (Theragra chalcogramma) en el Mar de Bering. Esta metodología hizo posible la estimación de la mortalidad por depredación del abadejo y los resultados sugirieron que el canibalismo podría ser un factor importante en el reclutamiento a la pesquería. Hollowed et al. (2000) incluyeron el efecto de la depredación causada por Atheresthes stomias, el lenguado del Pacífico (Hippoglossus stenolepis) y el lobo marino de Steller (Eumetopias jubatus), en un modelo separable de captura por edades de valoración del stock del abadejo en el Golfo de Alaska. La mortalidad causada por estos depredadores fue definida como un tipo de pesquería adicional. El método aplicado en estos dos modelos no consideró la retroalimentación entre depredadores y presas, la cual podría ser importante. También han sido desarrollados para el Mar de Bering oriental dos modelos que consideran este tipo de retroalimentación (Livingston y Jurado-Molina 2000; Aydin et al. 2002).

Para el Mar de Bering oriental han sido desarrollados un modelo de análisis de población virtual multiespecifico y un modelo predictivo multiespecífico (MSVPA y MSFOR, por sus siglas en inglés respectivamente) (Livingston y JuradoMolina 2000; Jurado-Molina y Livingston, 2002a). Estos modelos fueron desarrollados por el grupo de trabajo multiespecífico (Multispecies Working Group, MWG) del International Council for the Exploration of the Sea (ICES), basados en las hipótesis de interacciones multiespecíficas y preferencias del depredador propuestas por Anderson y Ursin (1977). El modelo MSVPA es una extensión del modelo de análisis de población virtual (VPA; Gulland, 1965) y estima los parámetros poblacionales y la mortandad por depredación basado en datos de captura por edad, ración del depredador y dieta del depredador. En Sparre (1991) y en Magnusson (1995) se pueden encontrar sendas descripciones más detalladas de las ecuaciones de depredación y las hipótesis usadas en el modelo MSVPA. 
mortality. This last parameter is estimated with the following equation:

$$
M 2_{p, a}=\sum_{i} \sum_{j} \frac{\bar{N}_{i, j} R_{i, j} S_{p, a, i, j}}{\sum_{p, a} \bar{N}_{p, a} W_{p, a} S_{p, a, i, j}}
$$

where $\bar{N}_{i, j}$ represents the average stock size of the predator $i$ of age $j . R_{i, j}$ is the annual ration of the predator and $S_{p, a, i, j}$ is the suitability coefficient for each predator-prey combination. These parameters reflect the diet composition of the predators relative to the food available (Sparre, 1991). The denominator represents the total suitable biomass available to the predator. In the denominator, $\bar{N}_{p, a}$ represents the average stock size of prey $p$ at age $a$ and $W_{p, a}$ represents its weight at age. Recruitment of age- 0 individuals in the model is assumed log-normal distributed. Some outputs of the MSVPA are inputs to the MSFOR, such as the suitability coefficients, initial population estimates and recruitment parameter estimates, therefore MSFOR requires a previous run of the MSVPA. MSFOR has been used in the consideration of some issues in fisheries management in the eastern Bering Sea (Jurado-Molina and Livingston, 2002a, b).

Due to the tendency of complex models to magnify input errors, it is necessary to carry out a sensitivity analysis focusing on those parameters with suspected uncertainty. Sensitivity analysis is a convenient methodology for model validation and the identification of parameters requiring further refinement. It also provides information on those components of the model important in determining the behavior of the response variables and the overall robustness of the model. Those input parameters are not expected to have a large impact on the output of the model. In particular, recruitment, suitabilities, stock size, fishing mortality and predation mortality are the outputs of concern in the MSVPA (Anonymous, 1991) and MSFOR.

\section{Methods}

We used the system defined in a previous work by Livingston and Jurado-Molina (2000). The species included in the MSVPA were walleye pollock (Theragra chalcogramma), Pacific cod (Gadus macrocephalus), Greenland turbot (Reinhardtius hippoglossoides), yellowfin sole (Pleuronectes asper), rock sole (Lepidopsetta bilineata) and Pacific herring (Clupea pallassi). The arrowtooth flounder (Atheresthes stomias) and northern fur seal (Callorhinus ursinus) were considered external predators because their stock sizes are provided externally from other sources (Sparre, 1991).

We took two different approaches to test the sensitivity of the model. The first analysis included a fractional factorial design for 16 variables with two levels of perturbation $( \pm 10 \%)$, as seen in table 1 . The second method was the individual parameter perturbation for the "other food" parameter.
El MSFOR es la contraparte predictiva del modelo MSVPA y usa el modelo exponencial para el pronóstico de la dinámica población:

$$
N_{a+1, t+1}=N_{a, t} e^{-(F+M 1+M 2)}
$$

donde $F$ representa la mortalidad por pesca, $M 1$ la mortalidad residual (causada por envejecimiento, inanición etc.) y $M 2$ la mortandad por depredación que es estimada con:

$$
M 2_{p, a}=\sum_{i} \sum_{j} \frac{\bar{N}_{i, j} R_{i, j} S_{p, a, i, j}}{\sum_{p, a} \bar{N}_{p, a} W_{p, a} S_{p, a, i, j}}
$$

donde $\bar{N}_{i, j}$ representa la magnitud promedio del stock del depredador $i$ de edad $j . R_{i, j}$ es la ración anual del depredador y $S_{p, a, i, j}$ es el coeficiente de adecuación para cada combinación depredador-presa; los parámetros $S$ reflejan la composición de la dieta de los depredadores con relación a las presas disponibles (Sparre, 1991). El denominador representa la biomasa total adecuada disponible para el depredador. En el denominador, $\bar{N}_{p, a}$ es la magnitud media del stock de la presa $p$ de edad $a$ y $W_{p, a}$ el peso por edad. El reclutamiento de la clase de edad 0 se supone con distribución Log-normal. Algunos datos de salida del modelo MSVPA se usan como datos de entrada para el modelo MSFOR, por lo que se necesita una corrida previa del MSVPA para hacer las simulaciones en el modelo MSFOR. El modelo MSFOR se ha usado en el análisis de algunas propuestas para el manejo pesquero del Mar de Bering oriental (Jurado-Molina y Livingston, 2002a, b).

Debido a la tendencia de los modelos complejos a magnificar los errores de entrada, es necesario llevar a cabo un análisis de sensibilidad enfocándose en aquellos parámetros que presentan cierta incertidumbre. El análisis de sensibilidad es una metodología útil para la validación de los modelos y la identificación de los parámetros que requieren un refinamiento adicional. También provee información sobre los componentes del modelo que son importantes en el comportamiento de las variables de respuesta y la robustez general del modelo. Se espera que esos parámetros de entrada no tengan un gran impacto en la salida del modelo. En particular, en el modelo MSVPA los resultados que más interesan son el reclutamiento, los coeficientes de adecuación (suitability coefficients), la magnitud del stock, la mortalidad por pesca y la mortalidad por depredación (Anónimo, 1991).

\section{Métodos}

En el presente trabajo se usó el sistema definido previamente (Livingston y Jurado-Molina, 2000), compuesto 
The number of runs required by a full $2^{\mathrm{k}}$ factorial design ( $k$ predictor variables) increases geometrically. However, in a full factorial design there tends to be redundancy in terms of an excess number of the interactions that can be estimated and sometimes in an excess number of variables that are studied. Fractional factorial design exploits that redundancy to reduce the number of runs in the analysis (Box et al., 1978).

The MSVPA model has potentially hundreds of response variables to analyze. However, only four response variables were chosen: average population for age-1 individuals and average $M 2$ of age-1 individuals of two species, walleye pollock and Pacific cod. These response variables were selected due to the importance of walleye pollock as dominant species in the Bering Sea in terms of annual catch and total groundfish biomass (Bakkala, 1993). These species also play an important role as predator-prey in the eastern Bering Sea (Livingston, 1993). Several input parameters could have been used as predictor variables in the sensitivity analysis. However, some were chosen for the analysis due to their importance in de seis especies y dos depredadores externos. En el sistema se incluyen las especies: abadejo de Alaska (Theragra chalcogramma), bacalao del Pacífico (Gadus macrocephalus), Reinhardtius hippoglossoides, Pleuronectes asper, Lepidopsetta bilineata y arenque del Pacífico (Clupea pallassi). Atheresthes stomias y el lobo fino del Norte (Callorhinus ursinus) fueron considerados como depredadores externos ("other predators") porque la magnitud de sus stocks se obtiene externamente de otras fuentes (Sparre, 1991).

Se usaron dos métodos para analizar la sensibilidad del modelo. El primero incluyó un diseño factorial fraccional para dieciséis variables con dos niveles de perturbación $( \pm 10 \%)$ como se aprecia en la tabla 1. El segundo método fue un análisis de perturbación del parámetro "otras presas".

El número de corridas requeridas para un diseño factorial completo $2^{\mathrm{k}}$ (k variables) se incrementa geométricamente. Sin embargo, en un diseño factorial completo tiende a haber redundancia en términos de un número excesivo de interacciones

Table 1. Fractional factorial design with resolution III for the sensitivity analysis: $X 1$, walleye pollock ration; $X 2$, walleye pollock terminal fishing mortality; $X 3$, northern fur seal ration; $X 4$, yellowfin sole terminal fishing mortality; $X 5$, arrowtooth flounder ration; $X 6$, Pacific cod residual mortality; $X 7$, yellowfin sole ration; X8, Pacific cod ration; X9, walleye pollock residual mortality; X10, Greenland turbot terminal fishing mortality; X11, Greenland turbot ration; X12, northern fur seal stock size; X13, arrowtooth flounder stock size; X14, Pacific cod terminal fishing mortality; X15, yellowfin sole residual mortality; X16, Greenland turbot residual mortality. The value assigned to X11 (Greenland turbot ration) was calculated as the product of X1, X2 and X3 (second row in table). A value of -1 represents a perturbation of $\pm 10 \%$.

Tabla 1. Diseño factorial fraccional de resolución III para el análisis de sensibilidad: X1, ración de abadejo de Alaska; X2, mortalidad terminal por pesca de abadejo de Alaska; X3, ración de lobo fino del Norte; X4, mortalidad terminal por pesca de Pleuronectes asper; X5, ración de Atheresthes stomias; X6, mortalidad residual de bacalao del Pacífico; X7, ración de Pleuronectes asper; X8, ración de bacalao del Pacífico; X9, mortalidad residual de abadejo de Alaska; X10, mortalidad terminal por pesca de Reinhardtius hippoglossoides; X11, ración de Reinhardtius hippoglossoides; X12, magnitud del stock de lobo fino del Norte; X13, magnitud del stock de Atheresthes stomias; X14, mortalidad terminal por pesca del Bacalao del Pacífico; X15, mortalidad residual de Pleuronectes asper, X16, mortalidad residual de Reinhardtius hippoglossoides. El valor asignado a X11 (ración de Reinhardtius hippoglossoides) se obtiene de multiplicar las variables X1, X2 y X3 (segundo renglón en la tabla). Un valor de -1 representa una perturbación de $\pm 10 \%$.

\begin{tabular}{rrrrrrrrrrrrrrrrr}
\hline & $\mathrm{X} 1$ & $\mathrm{X} 2$ & $\mathrm{X} 3$ & $\mathrm{X} 4$ & $\mathrm{X} 5$ & $\mathrm{X} 6$ & $\mathrm{X} 7$ & $\mathrm{X} 8$ & $\mathrm{X} 9$ & $\mathrm{X} 10$ & $\mathrm{X} 11$ & $\mathrm{X} 12$ & $\mathrm{X} 13$ & $\mathrm{X} 14$ & $\mathrm{X} 15$ & $\mathrm{X} 16$ \\
\hline & 1 & 2 & 3 & 4 & $1 * 2$ & $1 * 3$ & $1 * 4$ & $2 * 3$ & $2 * 4$ & $3 * 4$ & $1 * 2 * 3$ & $1 * 2 * 4$ & $2 * 3 * 4$ & $1 * 3 * 4$ & $1 * 2 * 3 * 4$ & + \\
1 & -1 & -1 & -1 & -1 & 1 & 1 & 1 & 1 & 1 & 1 & -1 & -1 & -1 & -1 & 1 & 1 \\
2 & -1 & -1 & -1 & 1 & 1 & 1 & -1 & 1 & -1 & -1 & -1 & 1 & 1 & 1 & -1 & 1 \\
3 & -1 & -1 & 1 & -1 & 1 & -1 & 1 & -1 & 1 & -1 & 1 & -1 & 1 & 1 & -1 & 1 \\
4 & -1 & -1 & 1 & 1 & 1 & -1 & -1 & -1 & -1 & 1 & 1 & 1 & -1 & -1 & 1 & 1 \\
5 & -1 & 1 & -1 & -1 & -1 & 1 & 1 & -1 & -1 & 1 & 1 & 1 & 1 & -1 & -1 & 1 \\
6 & -1 & 1 & -1 & 1 & -1 & 1 & -1 & -1 & 1 & -1 & 1 & -1 & -1 & 1 & 1 & 1 \\
7 & -1 & 1 & 1 & -1 & -1 & -1 & 1 & 1 & -1 & -1 & -1 & 1 & -1 & 1 & 1 & 1 \\
8 & -1 & 1 & 1 & 1 & -1 & -1 & -1 & 1 & 1 & 1 & -1 & -1 & 1 & -1 & -1 & 1 \\
9 & 1 & -1 & -1 & -1 & -1 & -1 & -1 & 1 & 1 & 1 & 1 & 1 & -1 & 1 & -1 & 1 \\
10 & 1 & -1 & -1 & 1 & -1 & -1 & 1 & 1 & -1 & -1 & 1 & -1 & 1 & -1 & 1 & 1 \\
11 & 1 & -1 & 1 & -1 & -1 & 1 & -1 & -1 & 1 & -1 & -1 & 1 & 1 & -1 & 1 & 1 \\
12 & 1 & -1 & 1 & 1 & -1 & 1 & 1 & -1 & -1 & 1 & -1 & -1 & -1 & 1 & -1 & 1 \\
13 & 1 & 1 & -1 & -1 & 1 & -1 & -1 & -1 & -1 & 1 & -1 & -1 & 1 & 1 & 1 & 1 \\
14 & 1 & 1 & -1 & 1 & 1 & -1 & 1 & -1 & 1 & -1 & -1 & 1 & -1 & -1 & -1 & 1 \\
15 & 1 & 1 & 1 & -1 & 1 & 1 & -1 & 1 & -1 & -1 & 1 & -1 & -1 & -1 & -1 & 1 \\
16 & 1 & 1 & 1 & 1 & 1 & 1 & 1 & 1 & 1 & 1 & 1 & 1 & 1 & 1 & 1 & 1 \\
\hline
\end{tabular}


the predation interactions and the dynamics of the species selected. The predictor variables were: annual ration of the predator, residual natural mortality $M 1$, terminal fishing mortality $F_{\text {term }}$ of each species and stock size of the "other predators". Sixteen input parameters were selected as predictor variables (table 1). These predictor variables were assigned randomly to a set of auxiliary variables $X_{i}$ to avoid pseudoreplication due to lack of randomness (table 1).

Due to the difficulty of carrying out a complete factorial design, which includes all possible combinations of all predictor variables, a fractional factorial design of resolution IV was developed by "folding over" a resolution III design (table 1). To complete the design of resolution IV, we folded over the resolution III design in such a way that the remaining 16 runs were obtained by switching the signs in the first set of 16 runs shown in table 1 . This design was used twice, once for positive perturbations and another for negative perturbations for a total of 64 deterministic runs of the MSFOR model. A simple way to analyze the sensitivity of the model is the coefficient of variation $\left(\sigma^{2} / \mu\right)$ of the response variable. This statistic indicates the overall sensitivity of the response variables to the complete set of perturbations implemented in the experimental design (Finn et al., 1986). The results from the sensitivity analysis were analyzed using response surfaces that included only the main effects (equation 3).

$$
y=\beta_{0}+\beta_{1} x_{1}+\beta_{2} x_{2}+\ldots+\beta_{16} x_{16}+\varepsilon
$$

where $y$ represents the response variable, $x_{i}$ the predictor variables, $\beta_{0}$ the intercept and $\beta_{i}$ the slope. It is assumed that the error $\varepsilon$ is normally distributed. The slopes are the absolute sensitivity coefficient measuring the absolute change due to a unit change in the predictor variable. A simpler interpretation of the effects produced by perturbations is achieved with the relative sensitivity coefficients defined with the following equation:

$$
\Delta y=\Delta x_{i}\left(\frac{\beta_{i}}{\sum \beta_{i}}\right)
$$

where $\Delta x_{i}$ represents the $10 \%$ perturbation in the parameter and $\beta_{i}$ the slope of the predictor variable. These coefficients measure the effects on the response variable produced by a $10 \%$ perturbation in each predictor variable. Following the methodology from the ICES Multispecies Group (Anonymous, 1991), a response variable was considered not sensitive to a $10 \%$ perturbation if the effect produced was smaller than $3 \%$.

The second method used to test the sensitivity of the MSVPA was an individual perturbation parameter (IPP) analysis for the "other food" parameter. This parameter accounts for the food observed in the predator's stomach, which does not originate from MSVPA prey species. We tested only the que pueden ser estimadas y, a veces, en el número excesivo de variables que son estudiadas. El análisis factorial fraccional explota esa redundancia para reducir el numero de corridas en el análisis (Box et al., 1984).

El modelo MSVPA tiene potencialmente cientos de variables de respuesta para analizar. Sin embargo, sólo se escogieron cuatro variables de respuesta: población media de individuos de un año de edad y $M 2$ media de la misma clase de edad de dos especies, abadejo de Alaska y bacalao del Pacífico. Estas variables de respuesta fueron seleccionadas debido a la importancia del abadejo como especie dominante en el Mar de Bering en términos de captura anual y biomasa total (Bakkala, 1993). Estas especies también juegan un papel importante como presas y depredadores en el Mar de Bering oriental (Livingston, 1993). Varios parámetros de entrada pudieron haber sido usados en el análisis de sensibilidad como variables predictivas, sin embargo, sólo unos cuantos fueron escogidos para el análisis debido a su importancia en las interacciones tróficas y la dinámica poblacional de las especies seleccionadas. Las variables predictivas incluidas fueron: ración del depredador, mortalidad residual $M 1$, mortalidad por pesca terminal $F_{\text {term }}$ para cada uno de los depredadores y la magnitud del stock de los depredadores externos. El total de parámetros de entrada fue 16 (tabla 1). Estas variables fueron asignadas al azar a un conjunto de variables auxiliares $X_{i}$ para evitar seudo replicación debido a falta de aleatoriedad (tabla 1).

Debido a la dificultad de llevar a cabo un diseño factorial completo que incluyera todas las posibles combinaciones de las variables predictivas, se desarrolló un diseño factorial fraccional de resolución IV "doblando" un diseño de resolución III (tabla 1). Para completar el diseño de resolución IV usamos el diseño de resolución III de tal forma que las 16 corridas restantes se obtuvieron cambiando el signo del primer conjunto de 16 corridas mostrado en la tabla 1. Este diseño fue usado dos veces, una para perturbaciones positivas y otra para perturbaciones negativas, para un total de 64 corridas deterministas del modelo MSFOR. Una forma sencilla de analizar la sensibilidad del modelo es el coeficiente de variación $\left(\sigma^{2} / \mu\right)$ de la variable de respuesta. Este estadístico indica la sensibilidad general de las variables de respuesta al conjunto completo de perturbaciones implementadas en el diseño experimental (Finn et al., 1986). Los resultados del análisis de sensibilidad también se analizaron con superficies de respuesta que incluyeron solamente los efectos principales (ecuación 3).

$$
y=\beta_{0}+\beta_{1} x_{1}+\beta_{2} x_{2}+\ldots+\beta_{16} x_{16}+\varepsilon
$$

donde $y$ representa la variable de respuesta, $x_{i}$ la variable predictiva, $\beta_{0}$ el intercepto y $\beta_{i}$ es la pendiente. Se supuso que el error $\varepsilon$ se distribuye normalmente. La pendiente representa el coeficiente de sensibilidad absoluta que mide el cambio absoluto derivado de un cambio unitario en la variable predictiva. Una interpretación más simple de los efectos producidos por 
assumption that is currently used in the assessments of the ICES Multispecies Group, which considers the "other food" parameter constant over time (Sparre, 1991). Based on predator consumption and estimates of total population of prey species, we estimated a value of $66,300,000$ tons for this parameter.

In the IPP analysis, the following perturbations were used: $\pm 75 \%, \pm 50 \%, \pm 10 \%, 20 \%, 100 \%, 200 \%$ and $300 \%$. Negative perturbations, smaller than $-75 \%$, were not used because the "other food" parameter and the total biomass become negative. The relative percent change (equation 5) of the average $M 2$ of age- 1 fish, and the average population size of age- 1 fish of all species were selected as response variables. We denoted the response variables with no perturbation as $N_{0}$ and $M 2_{0}$.

\section{Relative percent}

$$
=\left(\frac{M 2_{0}-M 2_{i}}{M 2_{0}}\right) \times 100
$$

\section{change in predation mortality}

\section{Results}

In general, the coefficients of variation of the response variables were small (fig. 1). The highest value corresponded to the average population of age-1 Pacific cod (11.22\%) and the lowest to the average predation mortality of age-1 walleye pollock $(2.37 \%)$.

All the response surfaces explained more than $90 \%$ of the variability observed. The response surface of all response

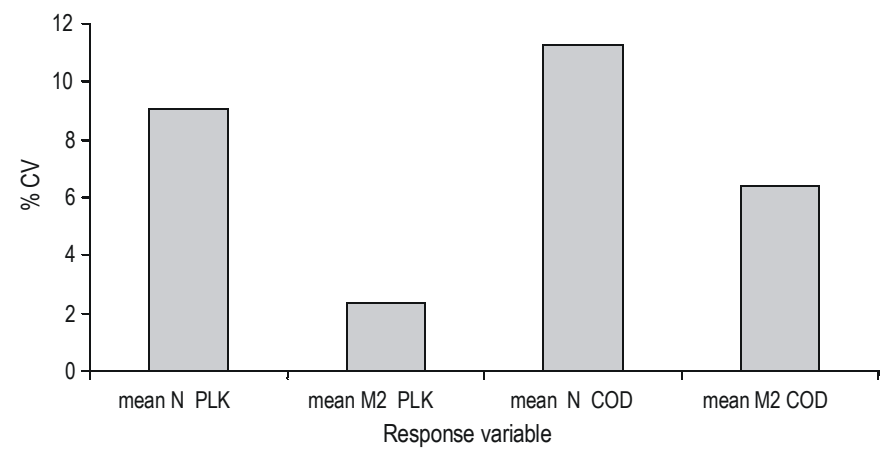

Figure 1. Coefficient of variation of the response variables analyzed with the fractional factorial design of resolution IV. PLK, walleye pollock (Theragra chalcogramma); COD, Pacific cod (Gadus macrocephalus); M2, predation mortality.

Figura 1. Coeficientes de variación de las variables de respuesta analizadas con el diseño factorial fraccional de resolución IV. PLK, abadejo de Alaska (Theragra chalcogramma); COD, bacalao del Pacífico (Gadus macrocephalus); M2, mortandad por depredación. las perturbaciones se logra con el coeficiente de sensibilidad relativa definido con la ecuación:

$$
\Delta y=\Delta x_{i}\left(\frac{\beta_{i}}{\sum \beta_{i}}\right)
$$

donde $\Delta x_{i}$ representa una perturbación del $10 \%$ en el parámetro y $\beta_{i}$ la pendiente de la variable predictiva. Estos coeficientes miden los efectos en las variables de respuesta producidos por una perturbación de $10 \%$ en cada variable predictiva. De acuerdo con la metodología del MWG del ICES (Anónimo, 1991), una variable se consideró no sensible a una perturbación del $10 \%$ si el efecto producido era menor a $3 \%$.

El segundo método para probar la sensibilidad del modelo MSVPA fue el análisis de perturbación del parámetro "otras presas". Este parámetro está constituido por el alimento observado en el estómago del depredador que no se origina de las presas incluidas en el MSVPA. Aquí sólo se analizó la hipótesis que se usa actualmente en las simulaciones hechas por el MWG del ICES que asume que el parámetro "otras presas" permanece constante en el tiempo (Sparre, 1991). Basado en el consumo del depredador y en estimaciones de población total de las especies de presas se estimó un valor de 66,300,000 toneladas para este parámetro.

En este análisis, se usaron las siguientes perturbaciones: $\pm 75 \%$, $\pm 50 \%, \pm 10 \%, 20 \%, 100 \%, 200 \%$ y $300 \%$. No fue necesario usar perturbaciones negativas menores que $-75 \%$ porque los valores del parámetro "otras presas" resultaron negativos. Para este análisis, el porcentaje de cambio relativo (ecuación 5) de la mortalidad por depredación media de los peces de un año de edad y la población de un año de edad se seleccionaron como variables de respuesta. $N_{0}$ y $M 2_{0}$ fueron usados para denotar los valores de las variables de respuesta sin perturbación.

\section{Cambio porcentual}

$$
=\left(\frac{M 2_{0}-M 2_{i}}{M 2_{0}}\right) \times 100
$$

\section{relativo en mortalidad por depredación}

\section{Resultados}

En general, los coeficientes de variación de las variables de respuesta fueron bajos (fig. 1). El valor más alto correspondió a la población media de un año de edad de bacalao del Pacífico $(11.22 \%)$ y la más baja a la $M 2$ media de abadejo de Alaska de 


\begin{tabular}{lccc} 
Table 2. Results of the regression with the average population size of age-1 walleye pollock as a \\
response variable. M1, residual mortality; TF, terminal fishing mortalities. \\
Tabla 2. Resultados de la regresión con la población de un año de edad de abadejo de Alaska \\
como variable de respuesta. M1, mortandad residual; TF, mortandad por pesca terminal; \%, \\
porcentaje de variabilidad explicada por la variable predictiva. \\
\hline Predictor variable & Coefficient & $t$-Stat & $P$-value \\
\hline Walleye pollock $M 1$ & 55417193 & 45.35668 & $2 \mathrm{E}-40$ \\
Intercept & $-4.5 \mathrm{E}+07$ & -36.5039 & $4 \mathrm{E}-36$ \\
Arrowtooth flounder ration & 32981837 & 26.99427 & $3 \mathrm{E}-30$ \\
Arrowtooth flounder numbers & 31910443 & 26.11738 & $1 \mathrm{E}-29$ \\
Walleye pollock TF & $-3.1 \mathrm{E}+07$ & -25.4181 & $4 \mathrm{E}-29$ \\
Walleye pollock ration & 22713318 & 18.58991 & $3 \mathrm{E}-23$ \\
Pacific cod $M 1$ & 14284293 & 11.6911 & $2 \mathrm{E}-15$ \\
Pacific cod ration & 11436981 & 9.360696 & $3 \mathrm{E}-12$ \\
Pacific cod TF & -7593194 & -6.21472 & $1 \mathrm{E}-07$ \\
Greenland turbot $M 1$ & 1766962 & 1.446185 & 0.1548 \\
Northern fur seal numbers & 1223062 & 1.001025 & 0.3219 \\
Greenland turbot TF & -891938 & -0.73001 & 0.469 \\
Yellowfin sole TF & -424888 & -0.34775 & 0.7296 \\
Greenland turbot ration & -245988 & -0.20133 & 0.8413 \\
Yellowfin sole ration & 219255.5 & 0.179452 & 0.8584 \\
Northern fur seal ration & 157986.8 & 0.129306 & 0.8977 \\
Yellowfin sole $M 1$ & -13663.2 & -0.01118 & 0.9911 \\
Walleye pollock $M 1$ & 55417193 & 45.35668 & $2 \mathrm{E}-40$ \\
Intercept & $-4.5 \mathrm{E}+07$ & -36.5039 & $4 \mathrm{E}-36$ \\
Arrowtooth flounder ration & 32981837 & 26.99427 & $3 \mathrm{E}-30$ \\
Arrowtooth flounder numbers & 31910443 & 26.11738 & $1 \mathrm{E}-29$ \\
Walleye pollock TF & $-3.1 \mathrm{E}+07$ & -25.4181 & $4 \mathrm{E}-29$ \\
Walleye pollock ration & 22713318 & 18.58991 & $3 \mathrm{E}-23$ \\
\hline & & &
\end{tabular}

variables had several significant slopes (absolute sensitivity coefficient) as shown for the average population size of age-1 walleye pollock in table 2 . However, in general, the relative sensitivity coefficients suggest that the response variables in the MSVPA were not sensitive to most of the predictor variables (effects $<3 \%$ ). Only one effect was greater than $10 \%$ (table 3). The average population of age-1 walleye pollock was sensitive to walleye pollock $M 1$. A $10 \%$ perturbation in $M 1$ produced a $6.4 \%$ increase in that response variable (table 3 ). The same variable was slightly sensitive to the ration of arrowtooth flounder (3.8\%), the stock size of arrowtooth flounder $(3.7 \%)$ and the $F_{\text {term }}$ of walleye pollock $(-3.6 \%)$. The average $M 2$ of age-1 walleye pollock was only sensitive to its $M 1$ (table $3)$. The average population of age-1 Pacific cod was sensitive to its own $M 1$ and $F_{\text {term. }}$. The largest effect (15.3\%) found in the analysis corresponded to $M 1$ of Pacific cod (table 3). Finally, the average $M 2$ of Pacific cod was not sensitive to most of the predictor variables with the exception of its $M 1$ and its ration un año de edad (2.37\%).

Todas las superficies de respuesta explicaron más del $90 \%$ de la variabilidad observada. La superficie de respuesta de la población media de abadejo de Alaska de un año de edad tuvo varias pendientes significativas (coeficiente absoluto de sensibilidad), como se muestra en la tabla 2. Sin embargo, en general, los coeficientes relativos de sensibilidad sugieren que las variables de respuesta no son sensibles a la mayoría de las variables predictivas (efectos $<3 \%$ ). Sólo un efecto fue mayor a $10 \%$ (tabla 3). La población media de abadejo de Alaska de un año de edad fue sensible a la $M 1$ del propio abadejo. Una perturbación de $10 \%$ en $M 1$ produjo un incremento de $6.4 \%$ en esa variable (tabla 3 ). La misma variable de respuesta fue ligeramente sensible a la ración de Atheresthes stomias (3.8\%), a la magnitud de la población de esta misma especie $(3.7 \%)$ y a la $F_{\text {term }}$ del abadejo (-3.6\%). La $M 2$ media del abadejo de Alaska de un año de edad sólo fue sensible a su propia mortalidad residual (tabla 3). La población media de abadejo de un año de 


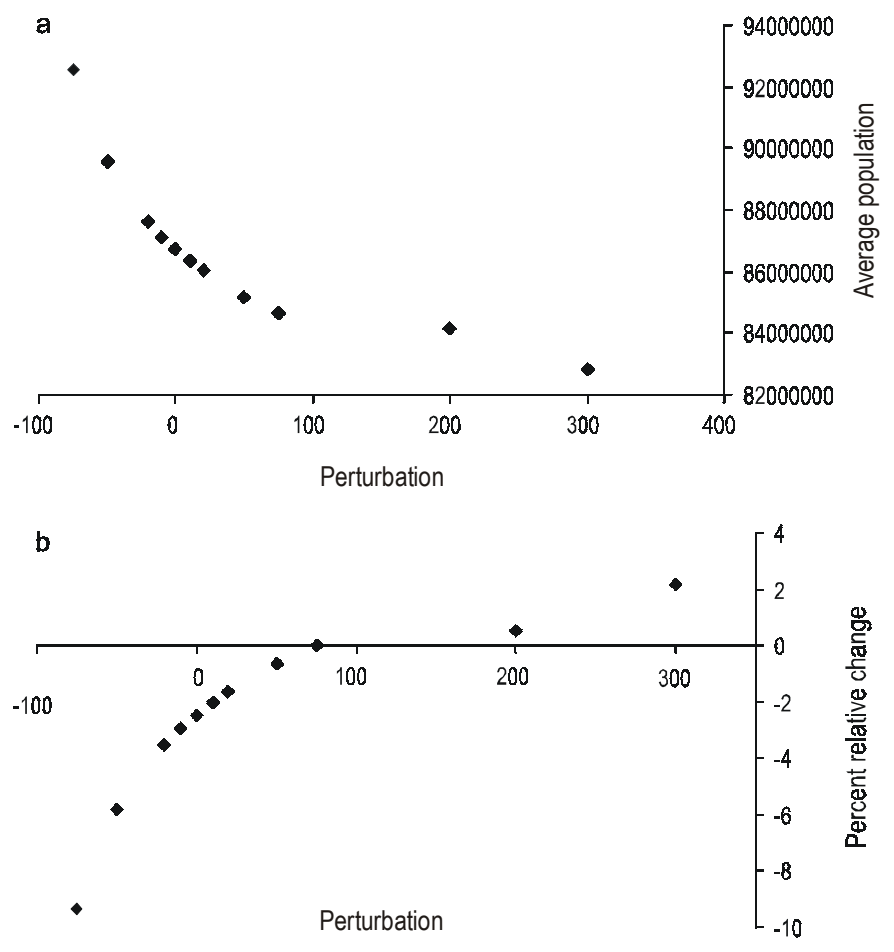

Figure 2. Changes in the average population of age-1 walleye pollock produced by perturbations in the "other food" parameter. (a) Average age-1 population. (b) Percent change of average age-1 population.

Figura 2. Cambios en la población media de abadejo de Alaska producidos por perturbaciones en el parámetro "otras presas". (a) Población media de un año de edad. (b) Cambios porcentuales de la población de un año de edad. edad fue sensible a su propia $M 1$ y $F_{\text {term }}$. El efecto más grande (15.3\%) correspondió a la $M 1$ del bacalao (tabla 3 ). Finalmente, la $M 2$ media del bacalao del Pacífico no fue sensible a la mayoría de las variables predictivas con excepción de su $M 1$ y su ración (tabla 3 ).

Los resultados del análisis de perturbación del parámetro "otras presas" correspondiente a la población de abadejo de Alaska de un año de edad se muestran en la fig. 2. Todas las perturbaciones produjeron valores de la variable de respuesta en el mismo orden de magnitud que el valor asociado con la corrida base $N_{0}$ (fig. 2a). La población media de un año de edad del abadejo de Alaska disminuyó cuando la magnitud de la perturbación fue incrementada con una relación asintótica en los extremos (fig. 2a). Por consiguiente, las perturbaciones negativas grandes produjeron cambios más pronunciados que los producidos por perturbaciones positivas grandes (fig. 2a, b). Similarmente, los cambios porcentuales relativos más pequeños de la variable de respuesta correspondieron a las perturbaciones positivas mayores con un rango de $-6.72 \%$ (perturbación de $-75 \%$ ) a 4.51\% (perturbación de 300\%).

Las variables de respuesta del resto de las especies mostraron tendencias similares. Sin embargo, la magnitud de los cambios fue diferente en algunos casos. Los cambios porcentuales relativos más pequeños en las variables de respuesta correspondieron al bacalao del Pacífico (fig. 3a). Los cambios porcentuales de Reinhardtius hippoglossoides y Lepidopsetta bilineata fueron menores a 10\% (fig. 3b). Para Pleuronectes asper, las perturbaciones produjeron cambios porcentuales menores a 3\%. Para el arenque del Pacífico los cambios por-

Table 3. Effects (\%) on the response variables produced by $10 \%$ perturbations in the predictor variables.

Tabla 3. Efectos (\%) en la variable de respuesta producida por perturbaciones del $10 \%$ en las variables predictivas.

\begin{tabular}{|c|c|c|c|c|}
\hline & $N$ age-1 plk & $M 2$ age- 1 plk & $N$ age- 1 cod & $M 2$ age- 1 cod \\
\hline Walleye pollock residual mortality & 6.35 & -3.72 & 0.12 & 0.46 \\
\hline Pacific cod residual mortality & 1.64 & 0.06 & 15.26 & -9.26 \\
\hline Greenland turbot residual mortality & 0.20 & -0.02 & 1.10 & -0.59 \\
\hline Yellowfin sole residual mortality & 0.00 & 0.07 & 0.00 & 0.14 \\
\hline Walleye pollock ration & 2.60 & 1.30 & 1.30 & -0.18 \\
\hline Pacific cod ration & 1.31 & -0.16 & 2.70 & 7.61 \\
\hline Greenland turbot ration & -0.03 & -0.03 & -1.24 & 0.66 \\
\hline Yellowfin sole ration & 0.03 & 0.03 & -0.10 & 0.04 \\
\hline Arrowtooth flounder ration & 3.78 & 1.51 & 1.09 & -0.62 \\
\hline Northern fur seal ration & 0.02 & 0.08 & -1.24 & 0.66 \\
\hline Walleye pollock terminal fishing mortality & -3.56 & 0.57 & 1.11 & -0.61 \\
\hline Pacific cod terminal fishing mortality & -0.87 & 0.08 & -6.53 & -0.53 \\
\hline Greenland turbot terminal fishing mortality & -0.10 & 0.02 & -0.04 & 0.03 \\
\hline Yellowfin sole terminal fishing mortality & -0.05 & -0.07 & -0.13 & -0.04 \\
\hline Arrowtooth flounder stock size & 3.66 & 1.50 & -0.06 & 0.00 \\
\hline Northern fur seal stock size & 0.14 & 0.08 & -0.10 & 0.04 \\
\hline
\end{tabular}


(table 3).

The results from the IPP analysis for the "other food" corresponding to the average population of age-1 walleye pollock, are shown in figure 2 . All perturbations produced values of the response variable in the same order of magnitude as the base run value $N_{0}$ (fig. 2a). The average population size of age1 walleye pollock decreased when the magnitude of the perturbation was increased with the asymptotic relationship in the extremes (fig. 2a). Therefore, large negative perturbations produced more pronounced changes than those produced by positive perturbations (fig. 2a, b). Similarly, the smallest relative percent change of the response variable (fig. 2b) corresponded to higher positive perturbations ranging from $-6.72 \%$ ( $-75 \%$ perturbation) to $4.51 \%$ ( $300 \%$ perturbation).

The response variable of the rest of the species showed similar trends. However, the magnitude of the changes was different for some cases. The smallest relative percent changes in the response variables corresponded to Pacific cod (fig. 3a). Relative percent changes for Greenland turbot and rock sole were smaller than $10 \%$ (fig. 3b). For yellowfin sole, the perturbations produced relative percent changes smaller than $3 \%$. For the Pacific herring the relative percent changes were also smaller.

In general, the relative percent changes in the predation mortality of age-1 fish were larger than those found for the average population of age- 1 fish. Again the response variables decreased when perturbations were increased and the relative percent change decreased when the perturbations increased. For walleye pollock, the relative changes were small, ranging from $-3.3 \%$ (for a $-75 \%$ perturbation) to $2 \%$ (for a $300 \%$ perturbation). Pacific cod again presented the smallest relative percent changes in absolute value $(<0.7 \%)$. For the Greenland turbot, the relative percent changes ranged from $-46 \%$ to $8.8 \%$. For the rock sole and Pacific herring, the relative percent changes were smaller than $15 \%$ for positive perturbations.

\section{Discussion}

The sensitivity analysis and response surface methods are useful to determine how the response variables are affected by perturbations on a set of parameters over specific regions of interest (Box et al., 1978; Schnute and McKinnell, 1984). They allow the identification of the relative importance of the changes produced, and provide feedback for the potential improvement of the model, identifying those parameters with potential problems. The response variables were chosen based on the importance of the walleye pollock and Pacific cod in the food web from the Bering Sea. Those response variables are also important for the population dynamics of walleye pollock, the dominant species in the Bering Sea.

Several approaches were taken to explore the sensitivity of the MSVPA model. A direct exploration of the coefficient of variation of the response variables indicated that their overall sensitivity is low. In the response surface we did not include two-way interactions in the model because the main effects

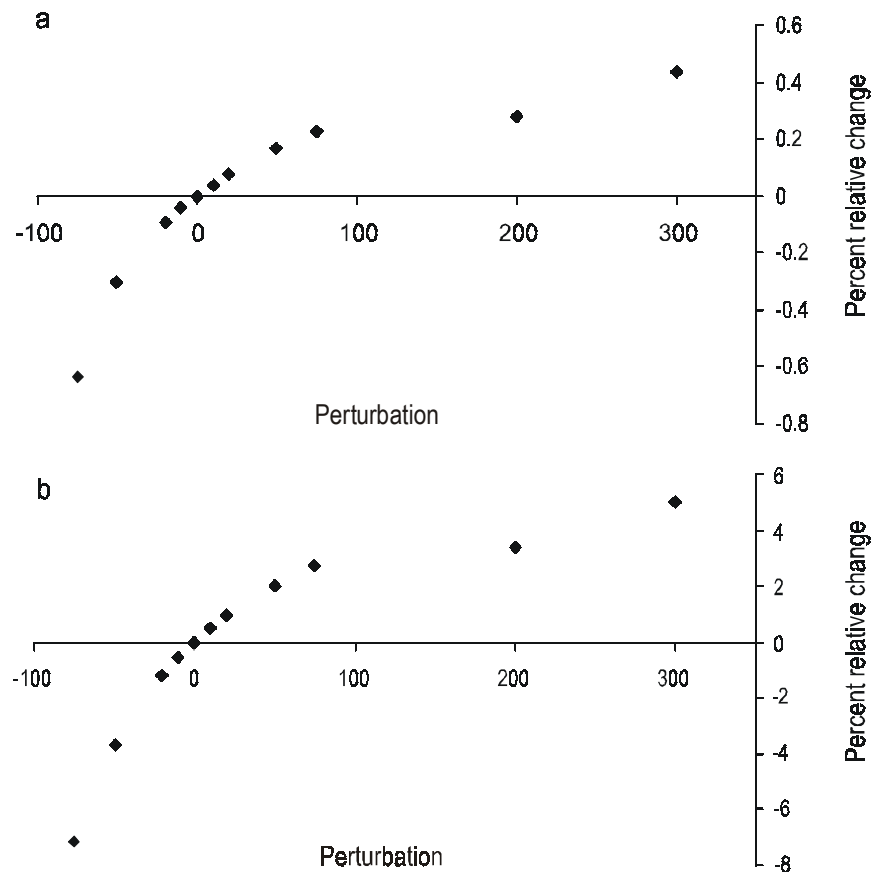

Figure 3. Percent changes in the average age-1 populations produced by perturbations in the "other food" parameter. (a) Pacific cod. (b) Rock sole (Lepidopsetta bilineata).

Figura 3. Cambios porcentuales en la población media de un año de edad producidos por perturbaciones en el parámetro "otras presas". (a) Bacalao del pacífico (Gadus macrocephalus). (b) Lepidopsetta bilineata.

centuales relativos fueron también bajos.

En general los cambios porcentuales relativos en la mortalidad por depredación de los peces de un año de edad fueron más grandes que los que se encontraron para la población media de la misma edad. Una vez más las variables de respuesta disminuyeron cuando las perturbaciones se incrementaron y los cambios porcentuales relativos disminuyeron cuando se incrementaron las perturbaciones. Para el abadejo de Alaska, los cambios relativos fueron pequeños en el rango de $-3.3 \%$ (perturbación de $-75 \%$ ) a 2\% (perturbación de 300\%). El bacalao del Pacífico una vez más tuvo los cambios porcentuales relativos más pequeños en valor absoluto $(<0.7 \%)$. Para Reinhardtius hippoglossoides, los cambios porcentuales relativos estuvieron en el rango de $-46 \%$ a $8.8 \%$. Para Lepidopsetta bilineata y el arenque del Pacífico, los cambios porcentuales relativos fueron menores que $15 \%$ para perturbaciones positivas.

\section{Discusión}

El análisis de sensibilidad y el método de superficie de respuesta son útiles para determinar cómo son afectadas las variables de respuesta por perturbaciones a un conjunto de parámetros en una región de interés específico (Box et al., 1978; Schnute y McKinnell, 1984). También permiten la identificación de la importancia relativa de los cambios producidos y provee retroalimentación para el potencial mejoramiento del 
explained most of the variability observed (more than $90 \%$ in all cases). Although some predictor variables had significant absolute sensitivity coefficients, the corresponding relative sensitivity coefficients showed that the response variable was not sensitive to that particular predictor variable. The relative sensitivity coefficients provide a clearer image of the effects produced by perturbations than the absolute sensitivity coefficients.

When the relative sensitivity coefficients were analyzed, we found that the response variables were not sensitive to most of the predictor variables of the predators. However, the response variables associated with walleye pollock were sensitive to some predictor variables from walleye pollock and arrowtooth flounder. The sensitivity of the response variables from the MSVPA model to some parameters can be partially explained by the trophic interactions observed in the population dynamics of the walleye pollock and Pacific cod. Some results suggested that the average population of age- 1 walleye pollock was sensitive to the ration of arrowtooth flounder. This result agrees with a previous work where the ration of arrowtooth flounder was important in determining the predation mortality and average population of age- 1 walleye pollock as shown by the large estimates of biomass consumption of walleye pollock by arrowtooth flounder (Livingston and Jurado-Molina, 2000). Earlier trophic analyses did not include the consumption of age- 1 walleye pollock by arrowtooth flounder in the estimation of the predation mortality of age- 1 walleye pollock (Livingston, 1993; Livingston and Methot, 1998). However, the present and previous results (Livingston and Jurado-Molina, 2000) suggest that arrowtooth flounder should be included as one of the main predators of age- 1 pollock. It is important to mention that the annual ration of arrowtooth flounder is determined based on estimates of growth increments and growth conversion efficiency; therefore, there is less concern regarding the uncertainty of this parameter. Other predators consuming important amounts of age-1 walleye pollock were the northern fur seal and Pacific cod (Livingston and Jurado-Molina, 2000). However, the response variables of walleye pollock were not particularly sensitive to the parameters of these predators. At this point, it is not easy to explain this discrepancy. The average population of age-1 walleye pollock was also sensitive to the stock size of arrowtooth flounder because this parameter is important in the estimation process of the predation mortality and therefore in the prey stock size (equation 2). Regarding the uncertainty of the estimates of population of arrowtooth flounder, we used those obtained from the single species groundfish stock assessment that could be considered the best estimate available (NPFMC, 1999).

The average population of age- 1 walleye pollock was also sensitive to the $F_{\text {term }}$ of walleye pollock. This parameter is important in the determination of the estimations of stock size in the MSVPA; however, there is uncertainty regarding this parameter, and to assess it, it is necessary to use an estimation approach using a likelihood profile or Bayesian analysis, both modelo, identificando los parámetros con problemas potenciales. Las variables de respuesta fueron seleccionadas con base en la importancia del abadejo de Alaska y el bacalao del Pacífico en la cadena alimenticia del Mar de Bering. Estas variables de respuesta también son importantes para la dinámica poblacional del abadejo, especie dominante en el Mar de Bering. Se utilizaron varios métodos para explorar la sensibilidad del modelo MSVPA. Una exploración directa del coeficiente de variación de las variables de respuesta sugirió que la sensibilidad global es baja. En las superficies de respuesta no se incluyeron las interacciones de primer orden en el modelo porque los efectos principales explicaron la mayoría de la variabilidad observada (más de $90 \%$ en todos los casos). A pesar de que algunas variables predictivas tuvieron un coeficiente de sensibilidad absoluta significativo, el correspondiente coeficiente de sensibilidad relativo mostró que la variable de respuesta no fue sensible a esa variable predictiva, en particular. Los coeficientes de sensibilidad relativa proporcionan una imagen más clara de los efectos producidos por perturbaciones que los coeficientes de sensibilidad absoluta.

Cuando se analizaron los coeficientes de sensibilidad relativa se encontró que las variables de respuesta no fueron sensibles a la mayoría de las variables predictivas de las especies de depredadores. Sin embargo, las variables de respuesta asociadas con el abadejo de Alaska fueron sensibles a algunas variables predictivas asociadas con el propio abadejo y con Atheresthes stomias. La sensibilidad de las variables de respuesta del modelo MSVPA a algunos parámetros puede ser explicada parcialmente con las interacciones tróficas observadas en la dinámica poblacional del abadejo de Alaska y el bacalao del Pacífico. Algunos resultados sugieren que la población media de abadejo de un año de edad fue sensible a la ración de Atheresthes stomias. Este resultado concuerda con resultados de trabajos previos donde la ración de Atheresthes stomias fue importante en la determinación de la mortalidad por depredación y el tamaño de clase promedio de abadejo de Alaska de un año de edad como lo muestran las estimaciones de la enorme biomasa de abadejo de Alaska consumida por Atheresthes stomias (Livingston y Jurado-Molina, 2000). Análisis tróficos previos no incluyeron el consumo de abadejo de Alaska de un año de edad por Atheresthes stomias en la estimación de la mortalidad por depredación del abadejo de un año de edad (Livingston, 1993; Livingston y Methot, 1998). Sin embargo, los resultados presentes y previos (Livingston y Jurado-Molina, 2000) sugieren que Atheresthes stomias debe de ser incluido como uno de los principales depredadores de abadejo de Alaska de un año de edad. Cabe mencionar que la ración anual de Atheresthes stomias se determina con base en estimaciones de incrementos en el crecimiento y la eficiencia de conversión de crecimiento, por lo tanto, hay menos preocupación relacionada a la incertidumbre de este parámetro. Otros depredadores que consumen cantidades importantes de abadejo de Alaska de un año de edad fueron el lobo fino del norte y el bacalao del Pacífico (Livingston y Jurado-Molina, 2000). Sin 
Jurado-Molina y Livingstone: Sensitivity analysis of the MSVPA for the Bering Sea

technologies not available in a multispecies context. Both walleye pollock response variables were sensitive to its own $M 1$. This parameter plays a role similar to the one played by the natural mortality $M$ in single-species models that are sensible to this parameter because it influences the stock size estimations. Therefore, the problems associated with $M$ in the single-species models are also found for $M 1$ in the MSVPA, among them, the uncertainty of its value and its indirect influence in the estimation of the predation mortality (equation 2). The results concerning walleye pollock suggest the importance of cannibalism in the dynamics of this species, and also that, in a multispecies context, the actions taken on arrowtooth flounder could have some effects on the dynamics of the walleye pollock. Therefore, it is important to take into account these two components when the walleye pollock fishery is managed.

Results for Pacific cod indicated that the response variables were sensitive to variables mostly related to itself, suggesting the importance of cannibalism in the population dynamics of this species. However, they were also sensitive to the annual ration of walleye pollock implying that predation by walleye pollock is also an important factor.

The results from the IPP analysis suggested that the changes in the average stock size and average predation mortality of individuals of each species originated by large perturbations in the "other food" parameter were small. In some cases, even the largest perturbations produced changes smaller than $1 \%$. It is important to point out that large values of "other food" are more likely than small values because in the estimation of this parameter we did not include all potential prey. Therefore, the small changes recorded for large positive perturbations suggest the robustness of the MSVPA model to changes in the "other food" parameter.

Results from this work indicate the importance of cannibalism and predation in the population dynamics of the walleye pollock and Pacific cod. They also suggest that the MSVPA model can be considered robust and agree with results from previous analysis (Anonymous, 1986; Finn et al., 1986; Anonymous, 1991) of the MSVPA and MSFOR models parameterized for the North Sea. These results are an important step in the validation of the MSVPA and MSFOR models, and helped in the identification of the parameters requiring further refinement, including the improvement of estimates of annual ration of predators and residual mortality. The uncertainty of the residual mortality can be addressed using statistical methdods (maximum likelihood and Bayesian methods), so it is necessary to develop multispecies models within this framework.

This model validation is necessary to incorporate multispecies models in ecosystem-based fishery management that will help to improve the sustainability of fishery resources in the eastern Bering Sea. However, it is necessary to further research and develop statistical multispecies models able to assess the uncertainty of parameters producing the largest effects in the embargo, las variables de respuesta del abadejo de Alaska no fueron particularmente sensibles a los parámetros de estos depredadores. En este momento no es fácil explicar esta discrepancia. La magnitud media de la población de abadejo de un año de edad fue también sensible a la magnitud del stock de Atheresthes stomias debido a que este parámetro es importante para determinar la mortalidad por depredación y, consecuentemente, la magnitud del stock de la presa (ecuación 2). En cuanto a la incertidumbre asociada a las estimaciones de la población de Atheresthes stomias, se usaron las obtenidas de las valoraciones del stock monoespecífico que son consideradas como las mejores estimaciones disponibles (NPFMC, 1999).

La población media de abadejo de Alaska de un año de edad fue también sensible a la mortalidad por pesca terminal del propio abadejo. Este parámetro es importante en la determinación de las estimaciones de la magnitud del stock en el modelo MSVPA; sin embargo, este parámetro tiene una incertidumbre importante y para valorarla es necesario usar un método de estimación de parámetros que utilice el perfil de verosimilitud o análisis Bayesiano, herramientas que actualmente no están disponibles en un contexto multiespecífico. Ambas variables de respuesta del abadejo de Alaska fueron sensibles a la $M 1$ del propio abadejo. La mortalidad residual juega un papel similar al papel jugado por $M$ en los modelos monoespecíficos que son muy sensibles a este parámetro, debido a que influencia las estimaciones de la magnitud del stock. Por consiguiente, los problemas asociados con $M$ en los modelos monoespecíficos se encuentran también para $M 1$ en el modelo MSVPA, entre ellos, la incertidumbre de su valor y su influencia indirecta en la estimación de la mortalidad por depredación (ecuación 2). Los resultados que involucran al abadejo de Alaska sugieren la importancia del canibalismo en la dinámica de esta especie, pero también sugieren que, en un contexto multiespecífico, las acciones tomadas para Atheresthes stomias pudieran tener algunos efectos en la dinámica poblacional del abadejo. Por consiguiente, para el manejo de la pesquería de abadejo de Alaska es importante tomar en cuenta estos dos componentes.

Los resultados para el bacalao del Pacífico sugirieron que las variables de respuesta del modelo MSVPA fueron sensibles a variables principalmente relacionadas con el propio bacalao del Pacífico, sugiriendo la importancia del canibalismo en la dinámica poblacional de esta especie. Sin embargo, también fueron sensibles a la ración anual de abadejo de Alaska lo que implica que la depredación del abadejo es también un factor importante.

Los resultados del análisis de perturbación de parámetros sugirieron que los cambios en la magnitud media del stock y la mortalidad por depredación media, originados por perturbaciones mayores en el parámetro "otras presas", fueron pequeños. En algunos casos aun las perturbaciones más grandes produjeron cambios menores a $1 \%$. Es importante señalar que los valores grandes del parámetro "otras presas" son más probables que los valores pequeños porque en la estimación de este parámetro no se incluyeron todas las presas potenciales. Con- 
MSVPA model.

\section{Acknowledgements}

This publication was partially funded by the Joint Institute for the Study of the Atmosphere and Ocean (JISAO), under the National Oceanic and Atmospheric Administration cooperative agreement number NA67RJ01555, contribution 855. We thank the staff of the Alaska Fisheries Science Center Stomach Lab for their work in the analysis of an immense amount of stomachs that provided the data for this research.

\section{References}

Anderson, K.P. and Ursin, E. (1977). A multispecies extension to the Beverton and Holt theory of fishing; with accounts of phosphorus, circulation and primary production. Meddr Danm. Fisk.-og Havunders. N.S., 7: 319-435.

Anon. (1986). Report of Multispecies Assessment Working Group. Copenhagen, 7-16 June 1989. ICES CM 1985/Assess: 9.

Anon. (1991). Report of Multispecies Assessment Working Group. Copenhagen, 7-16 June 1989. ICES CM 1991/Assess: 7.

Aydin, K.Y., Lapko, V.V., Radchenko, V.I. and Livingston, P.A. (2002). A comparison of the eastern and western Bering Sea shelf/ slope ecosystems through the use of mass-balance food web models. US Dept. Commer., NOAA Tech. Memo. NMFS-AFSC$130,78 \mathrm{pp}$.

Bakkala, R.G. (1993). Structure and historical changes in the groundfish complex of the eastern Bering Sea. NOAA Tech. Rep. NMFS 114.

Box, G.E.P., Hunter, W.G. and Hunter, J.S. (1978). Statistics for Experimenters: An Introduction to Design, Data Analysis and Model Building. John Wiley, New York.

Finn, J.T., Murawski, S.A. and Idoine, J.S. (1986). Response surface sensitivity of the North Sea Multispecies Virtual Population Analysis (MSVPA). ICES. Working documents M9, ad hoc Multispecies Assessment Group. Nov. ICES Copenhagen, Denmark.

Gulland, J.A. (1965). Estimation of mortality rates. Annex to Arctic Fisheries Workshop Group Report. Int. Counc. Explor. Sea CM 1965, Doc. 3, Mimeo. Copenhagen.

Hollowed, A.B., Bax, N., Beamish, R., Collie, J., Fogarty, M., Livingston, P., Pope, J. and Rice, J.C. (2000). Are multispecies models an improvement on single-species models for measuring fishing impacts on marine ecosystems? ICES J. Mar. Sci., 57: 707-719.

Jurado-Molina, J. and Livingston, P.A. (2002a). Mulispecies perspectives on the Bering Sea groundfish fisheries management regime. N. Am. J. Fish. Manage., 22: 1164-1175.

Jurado-Molina, J. and Livingston, P.A. (2002b). Climate forcing effects on trophically-linked groundfish populations: Implications secuentemente, los cambios pequeños registrados para las perturbaciones positivas sugieren que el modelo MSVPA es robusto a cambios en este parámetro.

Los resultados del presente trabajo sugieren la importancia del canibalismo y la depredación en la dinámica poblacional tanto del abadejo de Alaska como del bacalao del Pacífico. También sugieren que el modelo MSVPA puede ser considerado robusto y concuerdan con los resultados de análisis previos (Anónimo, 1986; Finn et al., 1986; Finn, 1986; Anónimo, 1991) aplicados en el Mar del Norte. Estos resultados constituyen un paso importante en la validación de los modelos MSVPA y MSFOR, y ayudaron a identificar los parámetros que requieren un refinamiento posterior, incluyendo el mejoramiento de estimaciones de la ración anual de los depredadores y la mortalidad residual. La incertidumbre de $M 1$ puede ser explorada con métodos estadísticos (máxima verosimilitud y métodos Bayesianos), por consiguiente, es necesario el desarrollo de modelos multiespecificos dentro de este marco.

Este tipo de validación del modelo es necesaria para poder incorporar los modelos multiespecíficos al manejo de pesquerías basado en el ecosistema, lo que ayudará a mejorar la sustentabilidad de los recursos pesqueros del Mar de Bering. Sin embargo se requiere más investigación y desarrollo de modelos multiespecíficos estadísticos capaces de valorar la incertidumbre de los parámetros que producen los mayores efectos en el modelo MSVPA.

\section{Agradecimientos}

Esta publicación fue parcialmente apoyada por el Joint Institute for the Study of the Atmosphere and Ocean (JISAO) bajo el convenio de cooperación con la National Ocegnic and Atmpssheric Administration, numero NA6 RJO1555, contribu-

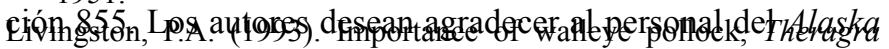

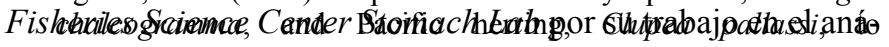

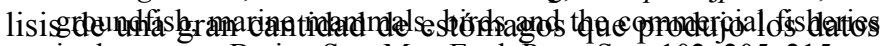
necin the eastern Pering SeabMar Ecol Prog Sepo 102: 205-215.

Livingston, P.A. and Methot, R.D. (1998). Incorporation of predation into a population assessment model of eastern Bering Sea walleye polfuckifo: Aisheranstoekr Assessuteres:Models. Alaska Sea Grant College Program, University of Alaska, Fairbanks.

Livingston, P.A. and Jurado-Molina, J. (2000). A multispecies virtual population analysis for the eastern Bering Sea. ICES J. Mar. Sci., 57: 294-299.

Magnusson, K. (1995). An overview of the multispecies VPA - theory and applications. Rev. Fish Biol. Fish., 5: 195-212.

NPFMC (1999). Stock assessment and fishery evaluation report for the groundfish resources of the Bering Sea/Aleutian Islands regions. North Pacific Fishery Management Council, 605 West 4th Ave., Suite 306, Anchorage, AK 99501.

Schnute, J. and McKinnell, S. (1984). A biologically meaningful approach to response surface analysis. Can. J. Fish. Aquat. Sci., 41: 936-953. 
Jurado-Molina y Livingstone: Sensitivity analysis of the MSVPA for the Bering Sea

Sparre, P. (1991). Introduction to multispecies virtual population analysis. ICES Mar. Sci. Symp., 193: 12-21 G46. 